\title{
Acordes Transatlánticos: Manuel Vázquez Montalbán y el tango como educación sentimental y política
}

MARINA CASTRILLO

\author{
Desde algún Manuel Vázquez Montalbán \\ hasta un chabón argentino y rasta \\ aquí está toda la humanidad \\ entre Sant Antoni y las Ramblas. \\ Como un puchero pero de razas \\ pasa un milagro que nunca pasa. \\ Se besan solos en un zaguán \\ la marroquí con el catalán. \\ "Rotos en el Raval", Otros Aires
}

La presente investigación se propone delinear un itinerario tangueromontalbaniano a lo largo de la producción del escritor, examinando la importancia emocional, cultural e histórica de los tangos en su obra desde una perspectiva transatlántica, con una atención especial a las novelas La muchacha que pudo ser Emmanuelle (1997) y Quinteto de Buenos Aires (1997), y a las inquietudes políticas que conllevan.

La canción popular, y de manera particular el tango, es para Manuel Vázquez Montalbán parte de su identidad, memoria colectiva, crónica de la sociedad y es un lugar singular de su geografía emocional. Muchos de sus libros podrían publicarse con banda de sonido: los cancioneros son como crónicas sonoras de otras épocas, las novelas de Pepe Carvalho contienen surreales playlists de un pinchadiscos "subnormal" y su obra poética acoge conciertos de orquestas mestizas bajo arcos urbanos del tiempo. De hecho, el propio autor lamentaba la falta de banda de sonido en el caso del Cancionero general del franquismo: "la música es la definitiva expresividad de la canción, la más determinante y en ocasiones autosuficiente. Pero sólo una coedición de discos hubiera podido salvar de cierto grado de cojera o ceguera a este libro, y en su imposibilidad 
debo moverme argumentalmente a partir de los datos que puedo proponer aquí: las letras" (Cancionero XXV). ${ }^{1}$

Hace ahora un poco más de veinte años que Vázquez Montalbán publicaba sus novelas de temática argentina (La muchacha y Quinteto) así como numerosos artículos, prólogos y entrevistas sobre Argentina y el tango, en un breve transcurso de tiempo. El análisis de las novelas argentinas de Pepe Carvalho debería considerar por los menos tres distintos aspectos complementarios que las convierten en un caso único en la serie de Pepe Carvalho y en un asunto exquisitamente complejo para los críticos: En primer lugar, es necesario señalar que la relación de Vázquez Montalbán con el tango es rica y polivalente. El escritor catalán fue del tango oyente, espectador militante, periodista musical, así como autor: algunos de sus tangos aparecen en poemarios y novelas, otros han sido musicalizados y cantados en obras teatrales y cinematográficas. Antes de la publicación de las novelas argentinas, ya había muchos años de versos de tangos (ajenos y propios), de experiencias de tango, que conformaban lugares en su escritura y constantes de sus collages narrativos, periodísticos y poéticos. En segundo lugar, es necesario notar el particular proceso de escritura de estas novelas. La muchacha que pudo ser Emmanuelle (publicada en agosto de 1997) y Quinteto de Buenos Aires (publicada dos meses más tarde) son el resultado del proceso de la novelización de los guiones originales escritos para la serie "Pepe Carvalho en Buenos Aires", en parte filmados en Buenos Aires unos años antes. Las dos novelas conforman un corpus narrativo único, son adaptación, ampliación y traducción literaria de un proyecto audiovisual no finalizado. Por último, es preciso subrayar el momento histórico en que fueron escritas y concebidas. Desde su columna del diario El País y otros espacios públicos Vázquez Montalbán denuncia reiteradamente los horrores de la dictadura argentina, y se suma a las voces que piden justicia por las víctimas y denuncian la impunidad de los militares. A finales de los 80, cuando el autor viaja a Buenos Aires para escribir la serie antes nombrada, Argentina vive su desencanto democrático. En 1997, el autor parece tener prisa por publicar sus novelas-crónicas sudamericanas debido a los sucesos políticos acaecidos: se podría argumentar que para Vázquez Montalbán la transición democrática y el desencanto en Argentina son como el otro lado del

\footnotetext{
${ }^{1}$ Sólo Cien años de canción y Music Hall (1974) fue publicado con discos. Hoy esas ediciones serían tecnológica y económicamente factibles, con libros electrónicos y servidores como YouTube, Spotify u Oxford Music Online.
} 
espejo de la española, que revelan historias compartidas de horrores transatlánticos, silencios, traumas, olvidos. Y en 1997 el juez español Baltasar Garzón parece poder cambiar o detener ese ciclo de impunidad y horrores.

\section{Tangos Transatlánticos}

En Crónica sentimental de España (1969/1971), en el Cancionero general del franquismo (publicado originalmente en 1972 como Cancionero general. 1939-1971 y ampliado en 2000) y otras obras, Vázquez Montalbán analiza la historia de los medios de comunicación de masas, la evolución de la radio, el cine y la televisión y el rol que tuvieron en la difusión y construcción de la identidad nacional española. El tango aparece a finales de los años veinte con la llegada del cine sonoro y la radio. Según Xavier Febrés, Barcelona era una parte importante del itinerario portuario del tango entre Buenos Aires y París, y de su desarrollo y difusión:

A principios del siglo XX, Barcelona era el puerto habitual de la línea marítima de comunicación de Argentina con Europa, una escala obligada entre la cuna del tango en Buenos Aires y su caja de resonancia mundial que fue París. De la condición de metrópoli portuaria y de la sintonía con las modas parisinas la ciudad de Barcelona extrajo aquella capitalidad terciaria, al mismo tiempo que músicos catalanes emigrados participaban en la expansión del género en Buenos Aires y París. (Febrés 14)

Entre los años veinte y treinta el tango llega al cine internacional. Orquestas, cantantes y bailarines argentinos y uruguayos hacen espectáculos por toda España y Carlos Gardel se convierte en el símbolo de la música sudamericana. Sin embargo, a pesar de su popularidad, el uso del lunfardo (la jerga de Buenos Aires) en las letras y el castellano cantado con acento rioplatense, hacen que el tango se considere música extranjera o extranjerizante. Para Vázquez Montalbán representa un elemento de modernidad, como parte de las modas musicales difundidas a través de los nuevos medios de comunicación de masas, frente al resurgir de los modelos nacionales tradicionales, como la copla o la zarzuela: "El interés por el folklore y la lírica tradicional que se suscita en los años veinte y treinta es una reacción frente al cuplé, el tango y los derivados del jazz que nos llegan desde culturas de masas mucho más desarrolladas. Había dos tradiciones al abasto para alimentar la reacción antiextranjerizante: la lírica tradicional y la tonadilla" (Cancionero XVIII). 
Este renovado interés por lo nacional y las reacciones anti-extranjeras serán aún más fuertes después de la guerra civil, como forma de control y propaganda nacionalista de la dictadura franquista y, si bien la música rioplatense pierde popularidad, se siguen cantando tangos en España. El autor incluye algunos de los más conocidos en la selección del Cancionero general del franquismo, clasificados según los diversos grupos temáticos propuestos en la obra. Estas composiciones siempre llevan la aclaración "tango" entre paréntesis bajo el título, según la costumbre de la época. Se nombran los autores de la letra y las músicas, nunca el año de publicación de los temas o sus intérpretes (ya que los años y sus intérpretes variarían en diferentes contextos nacionales). Los tangos seleccionados por Vázquez Montalbán son de temática político-social y, sobre todo, sentimental:

- Canción testimonial: "Cambalache" (1935).

- Canción sentimental: "A media luz" (1924), "Tango de amor" (año desconocido), "Adiós Muchachos" (1928); "Churrasca" (1934); "Limosna de amor" (1957); "Hijo" (1944); "Por ti a mi mare dejé" (milonga, año desconocido).

- Sabiduría convencional: "Yira, yira" (1929).

- Héroes y machismo: "Esta noche me emborracho" (1928), "Madre" (año desconocido).

El primer tango seleccionado e incluido en el Cancionero es, significativamente, "Cambalache" (música y letra Enrique Santos Discépolo, 1934): un tango de protesta escrito como reacción a la denominada Década infame (1930-1943), una descripción amarga e irónica sobre las injusticias y la falta de ética de las sociedades del siglo XX. "Cambalache" fue censurado en 1943 y por todas las sucesivas dictaduras argentinas. Desde entonces, cada generación que lo ha cantado, silbado o escuchado a escondidas, ha cooperado al aumento de su potencial subversivo (Colmeiro 37-38). El grupo Canción sentimental está encabezado por "A media luz", de Carlos César Lenzi, una de las joyas del tango. Algunos versos de este tango se van a convertir en obsesión literaria de Vázquez Montalbán, en un lugar de su geografía emocional, repitiéndose a lo largo de toda su obra. Como veremos más adelante, el tango para el autor catalán es educación sentimental y resistencia, de memoria urbana en "A media luz", de memoria política en el caso de "Cambalache".

En el documental "Barcelona tango" (2003) el director Nacho 
Garassino entrevista a muchas personas en Barcelona para contar la historia del tango en la ciudad: músicos, bailarines, exiliados sudamericanos, escritores. Entre ellos se incluye Vázquez Montalbán. El autor cuenta sus primeros recuerdos de tango en la ciudad, entre la imitación lejana y la parodia, convertidos en memoria de un sentimiento antibelicista en el marco de la posguerra franquista:

Yo aún de niño recuerdo de haber asistido al espectáculo de cantantes espontáneos de canción española pero también de tango, imitadores de Gardel o imitadores de los tanguistas en aquel momento de moda (...) "Silencio en la noche/Ya todo está en calma/El músculo duerme/La ambición descansa..." Que era como un tango antibelicista, que en el clima de la posguerra española pues sonaba muy bien y, bueno, también junto a eso la parodia, el intento de ridiculizarlo, como un escritor español, Benavente, que lo llamó 'lamento de cabrones' porque siempre está quejándose el cantante de que lo han dejado. Pues todo ello daba lugar a una relación ambigua con el género. (Garassino 2003)

Vázquez Montalbán canturrea en el documental el tango "Silencio", estrenado por Carlos Gardel en la película Melodía de arrabal (1932). ${ }^{2}$ La letra no tiene palabras en lunfardo, pero es una canción extranjera, con otro acento - el de Gardel- que cuenta una posguerra del pasado (tal vez la primera guerra mundial). La protagonista del tango es una mujer, madre de cinco hijos que mueren en el conflicto. La repetitiva descripción de rasgos femeninos, de costumbres maternas e infantiles suaviza el mensaje de horror ante la guerra cuando "todo ha pasado/renacen las plantas" y la sociedad está todavía paralizada por las ausencias y los recuerdos silenciados después de la batalla. Este tango, a pesar de llegar de tan lejos, en un clima represivo de censura como el de la posguerra española, se transforma para el público receptor y cantor en espacio popular de protesta contra todas las guerras. Extrañamente, este tango que representa una singular memoria personal y colectiva no está incluido en el Cancionero ni en ninguna de las obras posteriores del autor. ${ }^{3}$

\footnotetext{
${ }^{2}$ Música compuesta por Carlos Gardel y Horacio Pettorossi, letra de Alfredo Le Pera y Horacio Pettorossi.

3 Otro tango importante que brilla por su ausencia en Cancionero es "Volver" (1934), de Carlos Gardel y de Alfredo Le Pera, especialmente teniendo en cuenta que era uno de los tangos más apreciados por Vázquez Montalbán. La poética de la fuga y el regreso imposible a casa, la memoria de un pasado perdido, y el adiós a los sueños de abril de Vázquez Montalbán adquieren significados espe-
} 
La poetisa Hado Lyria, amiga de juventud del autor y traductora al italiano de la obra de Vázquez Montalbán, aporta una interesante apreciación generacional sobre la relación entre el escritor y el tango:

De nuestra infancia y adolescencia recuerdo sólo los tangos conocidos en todo el mundo, como "Caminito", "La cumparsita", "A media luz", "Adiós muchachos". A Manolo y a mí Gardel nos parecía (como a todos los jóvenes, dado que había muerto antes de que naciéramos) lejano como Rodolfo Valentino o las invasiones napoleónicas. Nadie tenía tocadiscos, escuchábamos lo que pasaban por la radio, controlado por la censura y la mala voluntad. Sólo más tarde comenzamos a comprender el valor profundo del tango, pero necesitamos tiempo antes de que entrase en nuestro "paisaje sentimental". Además, considera otra cosa: Manolo, que era muy sensible, temía la sensibilidad y estaba horrorizado por la "sensiblería". No sabía aceptar, por lo menos al principio, los tangos más "palabreros", en especial si con muchas expresiones no tan comprensibles para un español: por ejemplo, el tango "Cambalache”. (Castrillo 91)

Las palabras de Hado Lyria expresan la lejanía temporal y espacial del tango, la experiencia de asimilación que significaba para los jóvenes catalanes de aquella época escuchar la música rioplatense, así como la huella en la educación emocional que supuso eventualmente, y permite apreciar el futuro camino de aprendizaje y experimentación literaria con las formas del tango por parte del autor.

\section{Canción y textos migrantes}

Una marca característica de las diversas escrituras de Vázquez Montalbán es el uso de la técnica del collage. Su obra asemeja un complejo collage de materiales heterogéneos, que refleja su idea de la percepción de la realidad como fragmentos de imágenes rotas, inspirada en los versos de The Waste Land de T. S. Eliot (Izquierdo 189-190), y en la hibridación heterogénica del arte pop, en cualquier de los espacios literarios habitados por el autor.

Vázquez Montalbán utiliza frecuentemente collages transtextuales: innumerables citas, alusiones y homenajes o parodias a otros textos de

ciales en yuxtaposición con los versos del tango, relación intertextual que se concreta en su poemario "Pero el viajero que huye" (1991), cuyo mismo título está tomado de los versos de dicho tango: "pero el viajero que huye / tarde o temprano detiene su andar". 
muy diversa procedencia, empleando todo tipo de recursos literarios. En estos collages abundan las referencias literarias y a la cultura popular en forma de películas, publicidad o comics, y por supuesto, son recurrentes las referencias a canciones populares, uno de los materiales preferidos para la construcción de los collages montalbanianos (Salaün 277), en los que las canciones forman parte de un proyecto de recuperación de la memoria popular. Tal es la diversidad de lenguajes utilizados que tal vez se podría emplear la expresión collages transgenéricos, porque se superan todo tipo de fronteras genéricas y como resultado algunas obras no encajan en ninguno de los géneros literarios tradicionales.

El autor crea su propia geografía emocional insistiendo sobre un repertorio de ciertas imágenes y/o versos de canciones de forma casi obsesiva, plasmándolas y desarrollándolas en novelas y poesías, citándolas en artículos sobre política, deportes o comida, transformándolas y haciéndolas propias. Manuel Rico se ha referido a esta particularidad embriónica de la escritura montalbaniana como "semillas" literarias (Rico 26). Para Rico es en los poemas de Vázquez Montalbán que se pueden rastrear temas e imágenes que son como "semillas", es decir, que representan núcleos originarios que serán desarrollados plenamente en novelas posteriores:

el poema anticipa, en estado de máxima concentración, un proyecto narrativo. Así la novela será expresión del máximo nivel de desarrollo de un poema o de un conjunto de poemas (...) Poética y narrativa comparten el mismo universo mítico, idénticas preocupaciones morales y muy parecida dimensión estética. (Rico 26-27)

George Tyras considera otro aspecto de la transtextualidad montalbaniana que caracteriza como "textos migrantes", enfocándose más bien en la peculiaridad de los textos y/o temas que viajan por las escrituras del escritor catalán, entre géneros y estilos diversos, creando efectos de eco: "textos migrantes (...) piezas escritas específicamente para un texto narrativo se ven recogidas en un poemario, provocando que se oigan en él, no sólo sus propias notas armónicas, sino las de la novela de la que provienen originalmente" (Tyras 21). Un caso particular de este fenómeno migratorio de la escritura montalbaniana son precisamente los tangos. Los primeros tangos del autor ("Homage to tango" de 1970, y "Bailarín" de 1972) parecen ejercicios estéticos experimentales donde abundan los intertextos y las citas de otros tangos. Son composiciones lúdicas que se comportan como los textos migrantes descritos por Tyras: 
pasan del poemario a las novelas y a la prensa, como veremos más abajo.

En los artículos periodísticos de Vázquez Montalbán sobre literatura, política o música argentina muchas de sus consideraciones culturales, experiencias de espectador y viajero, e inquietudes políticas se convierten en "semillas", según la idea de Manuel Rico: núcleos narrativos desarrollados posteriormente en otras obras. El autor dibuja bosquejos que a veces en escrituras posteriores se convierten en imágenes nítidas como fotografías. Así, en el breve artículo "Corrientes 348 " de abril del 1984, escrito durante su primer viaje a Buenos Aires, hay palabras, imágenes, experiencias emocionales y vivenciales relacionadas con el tango que se van a desarrollar en poemas del libro $E l$ viajero que huye (1991) y se escenifican en prosa en Quinteto, como se verá más adelante. Otro ejemplo podría ser el del relato breve "Por una mala mujer", texto incluido entre los cuentos de El hermano pequeño (1994), pero escrito unos años antes. En el relato Carvalho tiene que desenmascarar a una trepadora sin escrúpulos, una de cuyas víctimas es un agente teatral de Buenos Aires en Barcelona, y otra es un industrial con negocios en Argentina. La historia le hace recordar a Biscuter un viejo tango, "La cieguita". Tiempo después, "la mala mujer" del título reaparece en Quinteto: Beatriz Maluenda, un personaje literalmente migrante. Carvalho la reencuentra en Buenos Aires con el mismo modus operandi criminal, iguales las víctimas (incluso algunos diálogos para describirlas) y los ecos de tangos del primer texto se convierten en espacio escenificado, en crónica musical de la novela argentina. En La muchacha aparece un tango que habla sobre la historia de una "mala hembra" y "Por una mala mujer" es precisamente el título de uno de los tangos interpretados en Quinteto por la cantante/personaje literario Adriana Varela, como se comentará más abajo.

El tango en la obra de Vázquez Montalbán es una melodía de colores lejanos, un sistema que puede sintetizar en pocos versos un universo narrativo, como un poema-souvenir rioplatense. Su poema "Homage to tango" es un texto migrante que aparece primero en el inclasificable y heterogéneo Manifesto subnormal (1970) y también está incluido en la versión ampliada de su primer poemario Una educación sentimental, en la sección miscelánea añadida "Liquidación de restos de serie" (1970).

COMO UNA CHIPIA

DE PANCHULEANDO

VAS POR LA CHUTRA

DEL VAGO ARRABAL 


\author{
PULIPA TIERNA, TIERNA PULIPA \\ DEL REJOSTIPO CHUTRA REAL \\ VIENEN PANDULAS \\ CHUTRAS DE INVIERNO \\ Y ALGO ME DICE: VAS A LLORAR (Memoria y deseo, 170)
}

Hay una reflexión lingüística en el poema, ya desde su propio título, "Homage to tango", un título en inglés con resonancia del francés, para referirse a un poema/canción de Argentina; la palabra homage (homenaje) además tiene un significado especial en el campo musical: homage to tango puede referirse a un tributo al tango, o a una pieza original que imita o recuerda las formas del tango. El poema está compuesto por 32 palabras, seis de las cuales (chipia, chutra, pulpa, panchuleando, rejostipo, pandulas) no son castellanas, catalanas o palabras del lunfardo porteño, aunque su fonética recuerda a este último. La importancia del sonido es evidente: el poema está escrito en mayúsculas, con marcadas repeticiones y aliteraciones, y con una sola coma como signo de puntuación. Para Hado Lyria, consiste básicamente en un juego eufónico y paródico:

Manolo utilizaba mucho las salmodias, como aquella de Galíndez mencionando las arepitas y otras especialidades latinoamericanas. Cuando le pregunté cómo traducirlas me dijo: pon lo que te parece, para mí se trata de eufonías nomás. Pienso que el tango en cuestión es un juego, una especie de "cadavre exquis" ligado a su idea de eufonía de la métrica filtrada por la ironía. (Castrillo 2011)

El "cadavre exquis" es un tipo particular de collage, un juego literario surrealista en el que los participantes van componiendo una frase al azar sin saber lo que los demás han escrito. La primera frase creada por los surrealistas fue Le cadavre exquis boira le vin nouveau y de ahí se deriva el nombre del juego." "Homage to tango" es un juego de eufonías tangueras y en cierto modo un "cadavre exquis", un juego intelectual de nonsense, en el territorio experimental de la escritura subnormal montalbaniana, que sin embargo trasmite cierta tristeza femenina, tanguera, enfatizada por el uso minimalista de las palabras clave "arrabal" y "llorar". Similar reflexión es ofrecida por el

\footnotetext{
${ }^{4} \mathrm{El}$ autor juega extensamente con este concepto, utilizando esta frase original como leitmotif musical en la novela El pianista (1985). Véase a este respecto la edición de Colmeiro (2017).
} 
protagonista/narrador de la novela El estrangulador (1994), donde "Homage to tango", de nuevo texto migrante, reaparece como tango favorito del protagonista, el cual da su propia explicación e interpretación del mismo:

Amo este tango porque demuestra que el medio es casi el mensaje, siempre que se haga trampa. Sin la palabra "arrabal" sabiamente situada y sin el final “...y algo me dice, vas a llorar" no sería un tango, sino una perversa tontería. Pero bastan siete u ocho palabras para situar al receptor en la convención de que ha escuchado un hermoso y melancólico tango. (El estrangulador 125)

Se puede afirmar que "Homage to tango" es un ejemplo característico de texto migrante que reaparece en múltiples escrituras del autor: poemarios, periodismo, novelas, y aun habremos de volver a él más adelante. Los tangos pueden aparecer en los sitios más insospechados en la obra de Vázquez Montalbán y reaparecer como textos migrantes en otras obras posteriores. El epígrafe de la primera novela protagonizada por Pepe Carvalho, Yo maté a Kennedy (1972), dentro de su escritura experimentalista subnormal, es un breve tango del propio autor: "Bailarín", que aparece firmado por unos tales Riel y Linyera. Vázquez Montalbán transforma en apellidos ficticios los sustantivos linyera -que en Argentina, Uruguay y Bolivia significa "vagabundo"- y riel, el carril de los ferrocarriles. La doble alusión es a las zonas de los alrededores de las estaciones de trenes y de las vías, que eran lugares donde solían vivir los linyeras, o vagabundos sin techos. O los hombres ocultos.

La clase media cayó en desgracia, se fue Mireya, murió Margot

y aquel muchacho de aristocracia

acobardado... retrocedió.

Lloró la causa de su partida,

lloró el origen de tanto mal,

mientras la guapa Barra Florida

cantó su coro sentimental (Kennedy 7)

La composición de "Bailarín" está construida con una métrica musical perfecta siguiendo los patrones tradicionales del tango: dos estrofas de cuatro versos decasílabos, en su mayoría con rima consonante, y un lenguaje no recargado de vocablos opacos o neologismos inventados, lo cual sugiere que el autor quería emular y dar 
la falsa impresión de un tango auténtico, y no un simple experimento lingüístico. $\mathrm{Su}$ aspecto fragmentario subraya asimismo ese efecto buscado de "autenticidad". Es significativo que el verbo llorar se repite dos veces en forma paralelística (llorar también es la última palabra de "Homage to tango"), sea por esa ineludible carga de tristeza y melancolía que el tango conlleva, sea por el yeísmo de la zona rioplatense que añade una nota de fonética tanguera para los oídos españoles. Por otra parte, hay referencias intertextuales inmediatas a otros tangos ya conocidos que no escaparían a un buen aficionado, como "Tiempos viejos" (con "la rubia Mireya"), "Margot" y "Adiós muchachos" (con la "barra querida").

El tango "Bailarín" es un conjunto de adioses, con sus referencias a heroínas imaginarias desaparecidas, perdidas entre la decadencia de clases sociales y las ilusiones, y al tango de despedida considerado el testamento de Carlos Gardel, "Adiós muchachos". Aunque la conexión con la cultura argentina es explícita en la letra del tango, no lo es en el contexto de la novela, lo que sugiere más bien una lectura simbólica del mismo como presagio. El tango preliminar podría ser la canción de adiós de Pepe Carvalho: para despedirse de la militancia comunista, su final como miembro de la CIA, y un adiós a todas sus identidades anteriores al convertirse en detective privado. Los adioses son únicos como las canciones de despedidas, dice el narrador:

Quisiera que siempre interpretaran esa música, que siempre la interpretara ese viejo arruinado por la historia y su propio continente semántico. No es cierto que cualquier paisaje sea bueno para una despedida, cualquier melodía propicia para el recuerdo. Quiero esta melodía en mi última despedida. (Kennedy 20)

La novela vanguardista, con subnormales cambios de voces narrativas, contiene fragmentos incongruentemente perfectos, como el siguiente, recitado desesperadamente durante una delirante discusión de pareja, que podría parecer una estrofa perdida de "Bailarín":

Ésta es la historia de una exasperación; amé la victoria y la revolución, el virus del consumo fue mi perdición, neurótico hice el juego a la contrarrevolución. (Kennedy 69)

La aparente indefinición de este tango en el contexto de la Guerra Fría en la novela, su aspecto inquietante y misterioso, se reabrirá posteriormente en otra novela montalbaniana. Después de 25 años, el 
mismo tango "Bailarín" es cantado por un personaje de Quinteto, Vito Altofini, el detective argentino socio de Pepe Carvalho en Buenos Aires. El asombrado Carvalho no hace ningún comentario al respecto, pero queda planteada una inquietud: "No registra don Vito el relativo asombro de Carvalho" (Quinteto 137). La aparición de este texto migrante, en una novela de emigraciones, exilios, y desapariciones, presenta ciertos interrogantes. ¿Se trata de un guiño al lector o de misteriosas conexiones entre los pasados de los detectives? ¿Cuándo había estado Pepe Carvalho en Buenos Aires? ¿Qué sabía Vito Altofini? ¿Es el tango un mensaje codificado? Esto son por ahora cuestiones pendientes sobre las que volveremos más adelante.

\section{Reflexiones sobre el tango}

Vázquez Montalbán ha mostrado su continuado interés por la música latinoamericana, y en particular por el tango, a lo largo de su obra. Una de sus primeras reflexiones críticas sobre el tango aparece en febrero de 1973, cuando publica en Triunfo una larga reseña sobre el estreno del espectáculo Tango de Mario Gas ("«Tango»o Maurice de Bellancourt pide explicaciones a la historia"). Se trata de una crítica de 4 columnas del espectáculo que tuvo lugar durante el invierno de 1973 en Barcelona, en la que el escritor discute la producción, y se detiene en el análisis de las actuaciones y el trabajo del director, enfatizando el componente histórico y político del tango. Claramente Tango lo ha dejado muy impactado, entre otros aspectos por la oportunidad de la recuperación y catalanización de los tangos, y de su reubicación dentro del imaginario de la nova cançó antifranquista, representada por Enric Barbat y Guillermina Motta. ${ }^{5}$

El tango en catalán se convierte en una experiencia completa, como una crónica musical de épocas e historias distintas: puede narrar las aspiraciones del proyecto-nación Argentina de la oligarquía de principios de siglo, contar la Europa de entreguerras y/o describir delicadas cuestiones políticas internacionales de manera irónica como pasos de una danza sensual entre los líderes de los dos bloques de la Guerra Fría:

...Un espectáculo como Tango en el que una breve línea, más sintáctica que

\footnotetext{
${ }^{5}$ Mario Gas (1947-) se convertiría por aquella época en colaborador de Vázquez Montalbán en la obra teatral/musical Guillermotta en el país de las Guillerminas (1973), y posteriormente sería el director de la adaptación cinematográfica de su novela El pianista (1998).
} 
argumental, conduce al espectador habitual de cabaret por los pasillos secretos que unen los tangos con la política argentina, la Europa feliz y confiada de primera preguerra del siglo y la Europa angustiada de entreguerras, neurótica doncella cuyos movimientos de acercamiento al "oso" soviético tiene bastante que ver con el tango [. . .] El resultado ha ratificado las enormes posibilidades que tiene la subcultura para dar constancia de las huellas digitales de los criminales y de los asesinos. Las enormes posibilidades que tiene el cabaret como centro de educación permanente. ("Tango" 49, énfasis añadido)

El cabaret del tango funciona a la vez como lugar de expresión performativa y de educación política, lo que entusiasma al escritor. Al mismo tiempo defiende la reutilización de estos lenguajes antiguos con usos recontextualizados, reciclados, siempre con ironía, señalando "las enormes posibilidades que conservan los abrigos cuando se le da vuelta con una cierta maña y con este simple truco recuperamos la servidumbre de los abrigos y nos liberamos de la servidumbre consumista de lo que lleva la etiqueta de novedad” (49). Para Vázquez Montalbán, el cabaret es parodia, humorismo, refugio expresivo contra el consumismo capitalista, y en definitiva, constituye un espacio de resistencia popular. Asi se muestra claramente en otras obras del propio autor, por ejemplo, el espectáculo de cabaret Flor de nit (1992), que recoge precisamente ese espíritu de resistencia popular, y de memoria histórica de la República y la guerra civil. También ahí se incluye un tango montalbaniano, "Lo más profundo es la piel", otro de los versos obsesivos del autor siguiendo a Paul Valéry, que se repite a lo largo de su obra como declaración paradójica anti-racionalista.

Otro texto coetáneo del autor, "Tango, tango, tango", publicado también en Triunfo en abril de 1973, con motivo del estreno en Francia de El último tango en Paris (1972), la polémica película de Bernardo Bertolucci prohibida por la censura franquista, sirve como pretexto para una de sus reflexiones más elaboradas sobre el tango. Es un artículo largo de nueve columnas con estructura y forma de ensayo periodístico, que recuerda los célebres ensayos de nuevo periodismo que componen su Crónica sentimental de España. En primer lugar, el autor explica la diferencia entre el tango en Europa -caracterizado por ser "tristeza ajena teatralizada", "nostalgia de baúl" y "fruto sentimental de exportación" (20) - frente a su sentir y significados en Argentina, como parte esencial de la historia musical del país, de sus inmigrantes y de sus mitos culturales y literarios. El autor señala igualmente la relación tango/literatura desde principio de siglo - con los ejemplos de Leopoldo 
Lugones y Rubén Darío- y las cualidades poéticas de los principales letristas de la música rioplatense (como Enrique Cadícamo y Enrique Santos Discépolo). Elogia igualmente a Ernesto Sábato y cita su libro Tango, discusión y clave (1963), por la significativa relectura del tango realizada por el argentino, centrada en varios aspectos esenciales: hibridación, sexo, descontento, bandoneón y metafísica. En medio del artículo, sin autor o título, reaparecen los versos del ya mencionado "Homage to tango", no en mayúsculas como en sus otras ediciones anteriores, y con el segundo verso cambiado: "DE PACHUELANDO" se convierte en "de pan couleando". Ya sea bien un cambio del autor o un error de imprenta, su función no varía en lo esencial: suena eufónicamente bien, pero nadie sabe exactamente lo que dice. Para el autor, parece que el tango tiene todavía algo de misterio musical y lingüístico, y es a la vez un juego intratextual típicamente montalbaniano que le permite experimentaciones literarias creativas de carácter "subnormal" dentro de un artículo periodístico.

Nuevamente el autor insiste en este artículo en el potencial subversivo del tango. Así señala que el tango puede ser rebelión contra la realidad falsificada por los medios, como es el caso del tango de Carlos Agustín Jonsson y Riobal, "Por culpa de la tv" (1962). Este tango de temática contemporánea, en el que los electrodomésticos ocupan un lugar central, habla de los recuerdos de un trabajador al volver a su hogar, la nostalgia de los olores de la cocina del pasado, cuando la comida no era "en pastillas", cuando la televisión no tenía hechizada a su esposa. La alienación consumista perpetrada por los medios de comunicación es un tema repetido en la obra de Vázquez Montalbán, especialmente en su etapa de escritura subnormal. Por esta razón, el autor define a este tango como una "tragicomedia televisiva" (21) que todos estamos viviendo. De esta manera, viniendo desde tan lejos, pero llegando tan cerca, el tango con sus acordes transatlánticos ridiculiza tragedias cotidianas con aplicaciones que superan las fronteras nacionales.

\section{La conexión argentina de Pepe Carvalho}

Al final de los años ochenta, las novelas de Pepe Carvalho contaban ya con varias adaptaciones cinematográficas y televisivas. Es un hecho generalmente aceptado por la crítica que Pepe Carvalho no tuvo mucha suerte en el cine y la serie producida por RTVE y dirigida por el argentino Adolfo Aristarain (1986) fue una desgraciada experiencia para Vázquez Montalbán. En sus propias palabras: 
Cada viernes por la noche contemplo la serie Carvalho, con una mano sobre los ojos, los dedos separados, eso sí, para ver y no ver. Para ver lo que reconozco y para tratar de no ver lo que me resulta irreconocible. La semana pasada tuve que dar crédito a mis ojos porque los tenía bien abiertos, pero me resultó difícil reconocerme como remoto argumentista de un capítulo titulado El mar, ese cristal opaco. ("Carvalho")

La consecuencia de su disgusto por los resultados de la serie fue la novela Asesinato en Prado del Rey (1987), una irónica venganza literaria para con el director argentino. En la novela el ficticio cineasta Arturo Araquistain aparece muerto y en la lista de sospechosos están los escritores que se han sentido traicionados por las adaptaciones de sus obras a la pantalla realizadas por Araquistain. Años más tarde, el recuerdo de la traición, ahora más lejana, parece dar paso a una cierta apreciación del director argentino. Así en Quinteto de Buenos Aires, una de las protagonistas, Alma, menciona la película Un lugar en el mundo (1992) de Adolfo Aristarain y comparte ciertas posiciones políticas expresadas en el largometraje, lo que resulta casi un elogio metaficcional, considerando el asesinato literario del director argentino ficticio en la novela mencionada anteriormente.

Vázquez Montalbán tuvo una nueva oportunidad de llevar a la pantalla a Carvalho en Argentina, pero no como una adaptación de sus novelas, sino a partir de la escritura de guiones de audiovisual posteriormente novelizados. Al contrario de las adaptaciones de obras literarias, los estudios teóricos sobre el proceso de novelización de una obra visual son casi inexistentes. Pepe Carvalho en Buenos Aires es un caso singular. A finales de los ochenta, el director de cine Luis Baroné y la productora Liliana Mazure, ambos argentinos, le proponen al autor realizar una serie de televisión con Pepe Carvalho en Buenos Aires. Vázquez Montalbán acepta y se toma unos meses en la capital argentina para escribir los guiones.

La culpa la tuvieron Liliana Mazure y Luis Baroné, no sólo provocadores de mi estancia en Buenos Aires - morían los ochenta o nacían los noventa, no recuerdo - para afrontar una serie televisiva sobre Carvalho, sino empeñados en enseñarme todos los Buenos Aires sagazmente ocultos, vigilados de cerca o de lejos por la presencia del obelisco. ("Adriana Varela solista en el Quinteto")

Por primera vez las aventuras de Pepe Carvalho en la pantalla nacen como guiones, y no como adaptación del cuento o novela o del autor. 
Vázquez Montalbán trabaja en equipo con el director y la productora, a quienes dedicará años después Quinteto de Buenos Aires, incluyéndolos además entre los personajes de la ficción. Sin embargo, el proyecto televisivo argentino tampoco fue afortunado. La empresa productora fracasó económicamente y el resultado fue la cancelación del proyecto. Solo uno de los guiones se llevó a la pantalla ("El hombre oculto"), primero como programa piloto, y posteriormente ampliado como largometraje (Pepe Carvalho en Buenos Aires). La banda de sonido de Pepe Carvalho en Buenos Aires contiene una serie de tangos escritos por el autor catalán en Buenos Aires y cantados por Adriana Varela, una nueva voz en el mundo del tango que empezaba entonces a ser reconocida. Formaba parte de una estrategia de la producción para realizar una serie de televisión de calidad, con una intérprete novedosa y apreciada, que había sido apadrinada por el reconocido veterano cantante de tango Roberto Goyeneche (1926-1994), "el Polaco". En algún lugar de Buenos Aires o de Montevideo debe existir la grabación inédita de los tangos de Manuel Vázquez Montalbán musicalizados por Jaime Roos y cantados por Adriana Varela, registrada para la serie que no se llegó a realizar.

Aunque el proyecto televisivo y cinematográfico fracasó, sin embargo, dio lugar a una serie de relatos literarios, desarrollados en dos novelas "argentinas" del autor. Ya en la novela El premio (1996) se adelantaba la propuesta de viajar a Buenos Aires en busca de su primo Raúl, un "medio-desaparecido" (El premio 316). En realidad, las aventuras argentinas de Pepe Carvalho comienzan en Barcelona antes de ese viaje preanunciado, con La muchacha que pudo ser Emmanuelle, novela breve publicada por episodios en el diario El País, del 3 al 30 agosto 1997, en la sección Relatos de verano. Cada episodio diario aparece con un resumen del anterior, el subtítulo del capítulo y acompañado de las ilustraciones de Fernando Vicente. La continuación de esta novela, Quinteto de Buenos Aires, se publica los primeros días de octubre de 1997. Ambas novelas juntas forman un corpus narrativo único, con personajes y temas en común, con escenas y diálogos que empiezan en La muchacha y se concluyen en Quinteto. Cabe preguntarse el porqué de esta configuración singular: ¿Qué decisión separa las novelas, que hasta hoy se siguen publicando individualmente? ¿Se debe a imposiciones editoriales (juntas alcanzarían las 650 páginas)? ¿Sería el deseo de publicar las historias de Pepe Carvalho en folletines, como en los principios de la novela negra, o el de llegar a un público de lectores más numeroso, distinto, playero, con una historia que denuncia los 
negocios que involucran a ex torturadores argentinos y a la nueva policía democrática española? ¿O quizás se trataría de preparar el interés de los lectores para la novela del otoño, como estrategia de marketing?

En La muchacha el detective investiga la desaparición de una actriz argentina en Barcelona, Palita (cuyo verdadero nombre es Helga Samuelson), la chica que hubiera podido ser la protagonista del remake argentino del éxito erótico francés de los años 70 (la serie de películas Emmanuelle protagonizadas por Sylvia Kristel). Las investigaciones de Carvalho lo relacionan con varios exiliados argentinos, algunos de los cuales han logrado buenas posiciones económicas en la sociedad catalana, otros que han acabado como vagabundos en los rincones más degradados de la ciudad, todos con nuevas identidades y pasados perdidos u olvidados. Con ellos comparte historias de fugas de la dictadura y consignas políticas como "Ni olvido ni perdón" de Margarita Nelken, que adquiere nuevos significados en América Latina, en especial por parte de las asociaciones de familiares de las víctimas de la dictadura, lo que sugiere un diálogo transatlántico y una cultura política de solidaridad sin fronteras (Colmeiro 120-121). Carvalho también comparte ideas sobre el rol cultural del tango como forma de educación sentimental, siguiendo uno de sus principios contraculturales: "A la hora de la verdad es preferible hacer caso a los boleros, a los tangos. Los libros no enseñan a vivir. Sólo te ayudan a enmascararte" (La muchacha 89).

La muchacha ofrece una introducción a la cultura, la música y a los traumas colectivos argentinos vistos desde Barcelona, antes de que Pepe Carvalho cruce el Atlántico para ir a buscar a su primo en Quinteto. La búsqueda de Palita lo conduce por teatros y cabarets decadentes de Barcelona, dónde el detective asiste a debates sobre el tango pre y postPiazzola, ensayos de espectáculos y explicaciones contextuales sobre el tango por parte de diversos personajes, como la conversación desarrollada entre el director Dieste y la cantante Dorotea a propósito de su interpretación del tango "Tú me dijiste que eras doncella": "Cuando dices... tú me dejaste, sin frente, rabo, chorna, ni plata... buena parte del público y sobre todo el de aquí no te entiende, estás utilizando el lunfardo. Por lo tanto has de intervenir más, con el tono de voz, con el desgarro, has de traducirlo a lo que el público va a entender si tú pones en ello la vida" (La muchacha 159).

El tango todavía se siente como música extranjera. Palita cantaba tangos para turistas con el vagabundo Cayetano, según los clichés callejeros, que así recuerda su historia: 
Cantábamos junto a las catedrales, los domingos. Barcelona, Tortosa, Gerona, Vic. Yo acabé cantando tangos a palo seco, vestido como los turistas suponen que han de vestir los cantantes de tangos, y ella posaba, con un traje rojo, un corte en la falda que le llegaba hasta la ingle. Ponía cara de enfadada y escuchaba mis tangos. Luego me pegaba una bofetada y cantaba ella. A los turistas les gustaba la escena. El cabrón que canta y la putón que escucha sin hacerle demasiado caso. (La muchacha 72)

A lo largo de La muchacha hay un tango que varios personajes tararean y del que cantan algunos versos, cuyo título es "Tú me dijiste que eras doncella", escrito por el propio autor. Al final de la novela el tango da título a un capítulo, reconvertido en "Vos me dijiste que eras doncella", y Pepe Carvalho -y los lectores- lo escuchan/leen por completo, cantado por la voz cansada y alcohólica de Dorotea Samuelsson: "Arranca el bandoneón como un aviso y se arrastra como una ráfaga de sentimiento en la que naufraga el resuello de los espectadores para que brote la voz avarelada, achavelada de Dorotea Samuelsson" (La muchacha 158). El autor inventa nuevos adjetivos para referirse a los estilos canoros desgarrados de la argentina Adriana Varela y de la mexicana Chavela Vargas. El tango desvela la terrible historia de Palita, a la vez que se ofrece como el cierre narrativo triste, solitario y final de su relato.

\author{
Chantajes tiernos \\ de mala hembra \\ te diste al piro con un chacal \\ me dejo huero \\ entre las gambas \\ el frío triste de un funeral. (La muchacha 158)
}

Las eufonías, las rimas y la construcción del poema recuerdan "Homage to tango", pero se diferencia por su mayor extensión (24 versos), y sobre todo porque el autor usa el lunfardo con propiedad de lenguaje, lo comprende, lo hace suyo, aquí no hay palabras inventadas. Por su temática y perspectiva, se trata de un tango testimonial en el universo de la novela, según la clasificación propuesta por el propio autor en Cancionero. Sus versos cuentan la dramática vida de Helga/Palita, repitiéndose a lo largo de las páginas como si fuesen la banda de sonido de la historia. Refuerzan la idea de Carvalho de que los tangos pueden ser un instrumento ideal para contar cierto tipo de historias. 
El peso de la historia acompaña los movimientos de los personajes. A la Sylvia Kristel argentina, la persigue su pasado: haber sido testigo de la guerra sucia, haber estado en el lugar equivocado, en el momento equivocado, en los sótanos de las detenciones clandestinas de la dictadura. Su desaparición se debe a un ajuste de cuentas, la eliminación de un testigo incómodo por parte de la vieja jerarquía argentina que se logra con la complicidad de ciertos personajes de arriba entre las fuerzas del orden en Barcelona y la ayuda de criminales locales. Quien encarga el homicidio y manipula a los contactos importantes, persiguiendo a Pepe Carvalho a lo largo de la novela, siguiendo órdenes, es "el gordo" argentino. En la última página de La muchacha dejamos a Carvalho, vigilado por Cayetano y el "gordo", mientras está tocando el timbre de un apartamento:

[Cayetano] Se fue caminando hasta las nuevas playas de la Ciudad Olímpica en plena amanecida y se sentó en un banco desde el que dominaba el encuentro entre el Pueblo Nuevo y aquella nueva Barcelona, Nueva Icaria, como la había bautizado la propaganda inmobiliaria antes de los juegos. Sabía que Carvalho pasaría por allí camino de casa de su tío, a interesarse por un posible viaje a Argentina. Sabía que el gordo no estaría lejos y era importante encontrárselos y que no le reconocieran. Carvalho llegó a las once de la mañana. Consultó el número de la escalera y pulsó el botón del sobreático. (La muchacha 164)

El sonido del timbre funciona como un corte de tipo cinematográfico, el cierre de la escena de Carvalho en La muchacha, quien reaparece más tarde en la terraza del mismo apartamento en la casa de su tío en la escena de apertura de la novela Quinteto de Buenos Aires:

Ante Carvalho la perspectiva de un terrado barcelonés, el viejo sentado en un sillón, en el horizonte la ciudad como si creciera a medida que se la mira. El viejo busca palabras que parece le cuesta encontrar. Tras los visillos de la ventana del ático dos mujeres maduras cuchichean mientras los miran de reojo. Carvalho permanece sentado en un sillón de mimbre a lo Emmanuelle (...) Carvalho se levanta, camina hasta la baranda de la terraza y recibe de la ciudad una propuesta síntesis de la vieja y la nueva Barcelona Olímpica, los últimos almacenes de Pueblo Nuevo, Icaria, la Manchester catalana, listos para el desguace, retaguardia de las arquitecturas eclécticas de la Villa Olímpica y el mar. (Quinteto 10)

Estas escenas están separadas textualmente por los dos meses transcurridos entre la publicación de las novelas. Se trata de la misma 
localización en ambas, focalizada desde la calle en La muchacha y, en Quinteto, desde lo alto, con una panorámica de las Barcelonas nuevas y viejas, de la gente en los balcones, del paisaje marítimo; una localización elegida como imagen de despedida de la ciudad y como preludio del viaje a América. El decorado de los sillones "a lo Emmanuelle" es otra señal visual de conexión entre las escenas. Igualmente, mientras el tío sigue hablando sentado el detective observa Barcelona desde la baranda y se imagina la ciudad porteña: "Cuando le llega la voz en off de su tío, Carvalho sonríe levemente. - Buenos Aires es una hermosa ciudad que se autodestruye" (Quinteto 11). El uso del término "voz en off" proviene de la narrativa cinematográfica, al igual que la técnica del contrapunto de los cortes de escena, elementos y técnicas que sugieren el propio proceso de la novelización de los guiones.

En Quinteto Pepe Carvalho viaja a Argentina en busca de su desaparecido primo Raúl, quien después de veinte años ausente de ese país decide regresar a buscar a su hija desaparecida y a resolver su pasado. En sus meses en Buenos Aires el detective catalán se involucra con los ex compañeros de Raúl e indaga otros casos investigativos paralelos, con lo que la novela toma la forma de una serie de microrrelatos de investigación dentro de un relato principal de desaparecidos. La acción de la novela coincide con los años del segundo gobierno de Carlos Saúl Menem (1989-1999), el presidente argentino que le concedió el indulto a los militares de la Junta militar encarcelados después de la dictadura, optando por el olvido histórico y el neoliberalismo económico como bases de la democracia.

Buenos Aires comienza mostrándose como espacio canción, y como geografía emocional. Carvalho llega a la ciudad, sube a un taxi a la salida del aeropuerto, y su primera parada en la ciudad significativamente es un espacio mítico del tango, la dirección mencionada en el célebre tango "A media luz". El detective le pregunta a Alma, cuñada de Raúl, que fue a recogerlo al aeropuerto:

- ¿Puedes hacerme una concesión sentimental?

- Estás en la capital del sentimiento (...)

- Corrientes, tres, cuatro, ocho. (Quinteto 23)

El taxista, cómplice con Carvalho, completa irónicamente los versos de la canción cantando: “iSegundo piso, ascensor...!" Durante el viaje Carvalho y Alma comienzan una conversación sobre tango, un diálogo que se va a desarrollar a lo largo de la novela y que concluirá en el mis- 
mo aeropuerto donde empezó, de vuelta a Barcelona. A lo que se asiste es a un cierto "pacto" alrededor del tango entre Alma, Carvalho y el lector, testigos el narrador y el taxista cantante. La novela, con ese viaje a Buenos Aires tan difícil de aceptar para el detective, está delineada por un itinerario de tangos. Si en La muchacha Carvalho piensa que a la hora de la verdad es preferible hacer caso a los tangos, más que a los libros, porque expresan emociones sin enmascararlas, en ese taxi Alma declara que los tangos, como las novelas, siempre mienten, y nadie la contradice. Carvalho comenta la fama que han tenido en Barcelona Gardel y también Irusta-Fugazot-Demare, trío de desconocidos para Alma, la cual pregunta si ha llegado a España Adriana Varela, una desconocida para Carvalho. "La que llegó a España fue Cecilia Rosetto [sic], una actriz formidable. Espero verla" (Quinteto 23), contesta el detective, primera mención de la cantante, que será reiterada múltiples veces en el transcurso de la novela, y a quien Pepe Carvalho buscará sin encontrar a lo largo de Quinteto. El trío Irusta-Fugazot-Demare estuvo de gira en España varias veces hasta poco antes de la guerra civil. Adriana Varela publicó su primer disco Tango en 1991 y Cecilia Rossetto hizo sus primeros espectáculos de tango en Barcelona en 1991 también. El "pacto" tanguero de la novela se ofrece como un itinerario de la historia del tango desde los años veinte hasta las artistas más novedosas de la actualidad, conformando así una especie de Crónica sentimental de Buenos Aires (ciudad descrita significativamente por Alma como "la capital del sentimiento").

Corrientes, 348 es una parada sentimental/musical obligatoria para Carvalho, al igual que para el autor, con emocionales conexiones autobiográficas. El escritor había viajado a Buenos Aires por primera vez en 1984, invitado por la Feria del Libro de la ciudad. En su columna en El País publica el 16 de abril de ese año el artículo titulado "Corrientes, 348 ", en el que manifiesta su obligada "peregrinación" a la calle de la canción a sabiendas de su desaparición: "Me lo habían dicho, lo había leído, está escrito; pero, a pesar de todo, nada más llegar a Buenos Aires me fui a Corrientes, 348" ("Corrientes, 348"). La dirección del tango había sido en su época un hotel por horas para encuentros amorosos. En la actualidad (como en 1984, y en la época de la escritura de la novela) es un anodino edificio de oficinas con un parking en la planta baja y un simple cartel que recuerda la canción. Vázquez Montalbán lamenta la torpeza urbana y cultural de los políticos responsables de la demolición de un lugar importante de la sentimentalidad popular: "Corrientes, 348, hoy es un edificio de oficinas y por la puerta de la calle se penetra a un parking con portero electrónico: los dos ojos, rojo y verde, de un 
semáforo que ni ladra ni deja de ladrar al amor" ("Corrientes, 348"). Pero como el autor señala en su artículo, queda la canción, y su melodía refuerza la memoria de un santuario urbano de amores clandestinos. La literatura, la música, y la imaginación sustituyen la prosaica realidad y devuelven una imagen melancólica del pasado perdido:

Corrientes, 348 seguirá siendo un lugar de peregrinación, y esa fachada oficinesca, desconocedora de crepúsculos interiores, será imaginativamente sustituida por la ensoñación de aquel edificio picadero en el que centenares de argentinos hicieron el amor con el correlato distante de la guitarra que, cómo no, lloraba. (“Corrientes, 348”)

El autor enfatiza el verbo "llorar" como palabra-símbolo tanguera, reiteradamente utilizada en sus propios tangos, y elige la palabra "peregrinación" como metáfora literaria para referirse a la acción obligada de ir a ver in situ el lugar del tango "A media luz". Es la peregrinación de un viajero cultural, de un creyente tanguero que se dirige a su santuario laico aun sabiendo su destrucción. Unos años después, en el poema "A pesar de que sus ojos" (Pero el viajero que huye), se repite el acto y el lenguaje de la "peregrinación" a Corrientes, la búsqueda infructuosa de la música de la memoria, con el recuerdo de amores fugaces, en un paisaje de olvido y desolación. El poema reescribe algunas palabras de la letra del tango original, adecuándose a la geografía sentimental de la poética de Vázquez Montalbán:

la muchacha bajará en Lima no volveré a verla

ni siquiera la recordaré mañana

cuando peregrine a Corriente tres

cuatro

ocho segundo piso ascensor

en busca de un gato de porcelana

incapaz de maullarle al amor (Memoria y deseo 392)

En estas diversas obras -novela, artículo, poema- Vázquez Montalbán no se resigna a que el espacio de la memoria sentimental se haya convertido prosaicamente en un estacionamiento, y sus textos son espacio de justicia urbana y reparaciones literarias. Es así que al final de la novela, en la calle Corrientes, en el número 348, aparece un auto con el cadáver de un hombre anciano, que resulta ser un agente de músicos de la época dorada del tango. Asesinato en Corrientes 348 se convierte 
en titular de los diarios, y el tango de nuevo está en las radios, en todos los medios. Vázquez Montalbán hace un homenaje al creador, a la historia de los amantes clandestinos, y cierra así de forma circular su itinerario tanguero de la memoria.

En Quinteto de Buenos Aires las referencias intertextuales a los tangos aparecen por todas partes, como parte de ese "pacto" tanguero inicial: de la misma forma que un taxista conmovido le canta "A media luz" a Pepe Carvalho, muchos de los personajes citan, comentan o cantan tangos clásicos como "Mano a mano", "Tomo y obligo", "Yira, yira", "Chorra" y "El pañuelito". En algunos casos se cita un solo verso, en general introducido por un "como dice el tango", casi como si fueran proverbios coloquiales y parte de la memoria colectiva popular. Otras veces las citas aparecen con título y autor: tal es el caso del epílogo de la novela, que se abre con un epígrafe que contiene una estrofa del tango "Magoya" de María Elena Walsh. En otros casos, se mencionan discos concretos de tangos, como Edmundo Rivero canta a Discépolo (1968), el regalo de despedida de Alma al detective ya en el aeropuerto. Alma y Don Vito son los personajes que más referencias hacen al tango a lo largo de la novela. Alma es profesora de literatura en la Universidad de Buenos Aires. En sus clases se debate sobre tango y poesía, y en una de ellas los estudiantes se enfrentan a un análisis del tango de "Juanito Laguna ayuda a su madre" de Astor Piazzolla y Horacio Ferrer, desde un punto de vista sociológico. Por su parte, Don Vito conoce todo tipo de tangos y los cita en momentos y lugares inesperados, citando incluso un tango inventado por el propio autor en la primera novela de Carvalho: "Bailarín" de Yo maté a Kennedy, que reaparece así de manera metaficcional 25 años después, abriendo nuevos enigmas. ¿A qué se debe la presencia de este viejo "texto migrante" en este nuevo contexto? ¿Cuántos secretos se esconden en el pasado de los agentes secretos y detectives privados? El tango acaso sirve para subrayar la conexión ideológica entre la Guerra Fría y la Guerra Sucia o para sugerir la posibilidad de que Carvalho había estado alguna vez en Buenos Aires. Todas estas incógnitas surgidas por la aparición del tango no son completamente despejadas en la novela, pero de alguna manera la conexión tanguera refuerza la circularidad del ciclo narrativo de la serie Carvalho.

Quinteto es un viaje a la estación central del tango. La música se hace crónica sentimental de Argentina, de su pasado y presente en la novela. El tango es identidad y memoria, estructura y técnica narrativa. Los protagonistas viven un reencuentro tardío con el tango y la canción 
emblema del quinteto de compañeros de lucha durante la dictadura es de hecho un tema rock. El misterio de la novela tanguera de Vázquez Montalbán se esconde en un rock de protesta del pasado, convertido en melodía infantil (Pardo 153), compuesto veinte años antes. El rencuentro imposible con el pasado, tanto musical, como político y familiar, es uno de los temas principales de la novela, y el tango "Volver" es evocado constantemente, especialmente a través de la expresión "veinte años" que subraya el contraste del pasado y el presente, y como señala Musci,

adquiere un significado importante en una novela como referencia intertextual que también habla de exilios y regresos. En todas las ocasiones "veinte años" evoca la espesura del tiempo pasado entre unos sucesos que marcaron definitivamente a los personajes y este presente en el que intentan reconstruir sus propias vidas, individual y colectivamente. Veinte años es la edad que tiene la hija desaparecida, el tiempo que pasó para que los cuerpos de Raúl y Alma volvieran a encontrarse, el que hace imposible para Raúl volver a ser el que fue, incluso el tiempo que necesita un whisky para alcanzar excelencia (...) El cliché adquiere su verdadero sentido al final de la novela cuando los padres se reencuentran con la hija y participan en la marcha de La noche de los lápices. (Musci 9)

Si bien todo esto es cierto, en mi opinión se acumula otro significado adicional, de carácter histórico y transatlántico: La historia argentina y española comparten similares procesos políticos en sus transiciones postautoritarias, y se cumplen en ese momento también veinte años de la promulgación la ley de Amnistía de octubre de 1977, denominada como el "pacto de olvido", que marcó la transición democrática en España. En ambos casos, el olvido y la desmemoria fueron el resultado. Volveremos sobre esta cuestión en la sección final.

En Quinteto, los protagonistas se reúnen en Tango amigo, un lugar de la Buenos Aires alternativa inspirado en el local El Berretín del barrio bohemio de San Telmo. En el escenario del tango-cabaret el presentador Norman Silverstein -mezcla de animador histriónico y actor fracasado, ex compañero de lucha política de Raúl- recita una serie de monólogos cínicos y demenciales sobre la cultura argentina, el tango y los horrores de la dictadura. Allí Adriana Varela canta tangos (creados por el autor para el proyecto audiovisual) que poetizan los hechos narrados en la ficción y, como parte del collage narrativo, constituyen un momento de deleite, pausa y reflexión. En ese sentido, las actuaciones de Adriana Varela recuerdan el ritual de la comida o de la quema de libros en la serie del detective Carvalho, que funcionan digresivamente como elementos 
reflexivos y retardatorios de la acción. Los tangos que canta Adriana Varela en Tango amigo son: "Buscás", "Hombre oculto", "Por una mala mujer", "Borges Júnior", "Zapatos de gamuza", "Comen para olvidar" y "Recuerda la nada". Quizás sea "Hombre oculto" el tema principal de la banda de sonido de la narración, con multiples resonancias: la letra nos cuenta al mismo tiempo la historia del fugitivo Raúl, del pasado secreto de Carvalho, del escondido Favila, de las identidades del Capitán y de Robinson, todos ellos en cierta manera son hombres ocultos. Dice en cierto punto Carvalho: "Soy un detective privado. Siempre buscamos a un hombre oculto, a una mujer oculta. Pero esta noche no es Raúl ni la Rosetto [sic]" (Quinteto 201). Y si bien la novela revelará a muchos hombres ocultos, Cecilia Rossetto permanecerá como la mujer oculta, desaparecida, a lo largo de todo el libro.

El último tango, más que cantado, recitado por Adriana Varela, deja a todos los espectadores de Tango Amigo boquiabiertos: "Se han quedado sin aliento Adriana, Carvalho, el público, Güelmes lo recupera para susurrar al oído de Carvalho: -¿Esto es un tango? ¿Tango de cámara quizás?" (Quinteto 510). Se trata de un poema de Vázquez Montalbán, incluido en su poemario Ciudad, también publicado, como ambas novelas, en 1997 y aparecido anteriormente en la novela $E l$ estrangulador. Su título en el poemario es "Dos", un texto migrante que pasando al Quinteto cambia la métrica a favor de un ritmo constante, centrándose en la memoria, en la ciudad, en el hueco dejado por miles de ausencias que son el rasgo que más le impresiona de Argentina, como fue recogido en el diario El País por Amelia Castilla:

"Una noche, un tipo que me caía muy bien, de esos que se saben de memoria a Borges, me pidió que escogiera un rasgo que me hubiera impresionado por encima de cualquier otro sobre Argentina. Le respondí que los vacíos dejados por 30.000 seres humanos, los llamados desaparecidos". Sin inmutarse apenas, el beato de Borges le contestó que eran pocos los desaparecidos y que todavía quedaba mucha gentuza por exterminar. (Castilla)

Quinteto es una novela de denuncia de las ausencias, de investigación sobre los vacíos y los desaparecidos, y contiene una notable despresencia: la de la cantante Cecilia Rossetto. Se la nombra explícitamente ocho veces, Pepe Carvalho espera ver uno de sus espectáculos en cuanto llega a Buenos Aires y la busca reiteradamente, al final no lo logra. En la última página de novela el detective acaba preguntándose "¿Había estado alguna vez en Buenos Aires? Ni siquiera había conseguido ver el show de Cecilia Rosetto [sic]" (Quinteto 522). 
El detective vuelve a Buenos Aires en Milenio (2003) y entonces finalmente logra asistir a uno de sus espectáculos, como si fuera una cuenta pendiente con la ciudad y el tango, y reforzando la fuerte sensación de circularidad que la novela da al ciclo narrativo carvalhiano.

\section{Conclusiones ocultas}

El ritmo de la producción de estas dos novelas sugiere que Vázquez Montalbán tenía mucha prisa por publicar sus historias argentinas. La cantidad de errores lo sugiere, hay grandes irregularidades en el uso del castellano de España y Argentina en La muchacha, y excesivas confusiones de nombres de personajes en Quinteto: el socio del protagonista Raúl es Roberto Améndola (44-47), después Ricardo (4849, 53-54), de nuevo Roberto $(69,81,91,99-100)$ y al final Roberto Améndola Labriola $(101,105)$. El apellido de Alma es sobre todo Modotti, pero también Mototti, Medotti, Menotti. A este respecto, varios amigos y colaboradores del autor han incidido sobre este aspecto apresurado de la obra. ${ }^{6}$ La prisa del autor, en mi opinión, se podría relacionar con la inesperada orden de captura internacional de 98 militares argentinos emitida por el juez español Baltasar Garzón en marzo del 1997, acusados de la desaparición de ciudadanos españoles durante la dictadura argentina 1976-1983. Los juicios habían sido bloqueados en Argentina por las leyes de Punto Final y Obediencia Debida (1986-1987), y los pocos detenidos habían sido liberados con el indulto adicional de 1989. Las acciones del juez Garzón representaban una esperanza contra la cultura del olvido a ambos lados del Atlántico, y el comienzo del proceso de reapertura de los juicios por las víctimas de las dictaduras, finalmente iniciado en el 2005 en Argentina y en el 2007 en España (aunque posteriormente descarrilado). Las novelas argentinas de Vázquez Montalbán son espacio de reflexión y de construcción de esperanzas que atraviesan fronteras, y que forman parte de una lucha colectiva, solidaria y transatlántica.

\footnotetext{
${ }^{6}$ Hado Lyria ha tenido inconvenientes en la traducción de la obra al italiano debido a estos pequeños errores, según ella debidos a la prisa y una cierta dislexia del autor. En la novela la cantante argentina es siempre nombrada como "Cecilia Rosetto". El escritor argentino Horacio Vázquez Rial, exiliado en Barcelona y gran amigo de Vázquez Montalbán, sugiere cierta dureza de orejas y la ausencia de un editor argentino prometido por la editorial Planeta (Castrillo 82-83).
} 
En octubre del 2013, durante el Congreso "Diez años sin Manolo" (Universitat Pompeu Fabra, Barcelona) el profesor José Colmeiro planteaba una incógnita ante la diferencia entre la edición argentina de Quinteto respecto a la española: la desaparición de Cecilia Rossetto del texto argentino. Cuando tuve esa edición entre mis manos pude comprobar que la confusión de los Ricardos y Robertos, al igual que todas las variaciones del apellido de Alma (Modotti, Menotti, Mototti, etc.) están ahí, idénticas en las dos ediciones. El castellano argentino improbable, igual; tan sólo se vislumbra una pequeña gran diferencia: todas las frases que contienen el nombre de la cantante y actriz argentina Cecilia Rossetto efectivamente desaparecen sin dejar rastro. Desde la sede general de la editorial Planeta en Buenos Aires la única información que obtuve telefónicamente de uno de los editores es que los libros de escritores españoles se someten a un proceso llamado castillar, según la jerga de la oficina argentina: acción de hacer astillas del castellano original para argentinizarlo. Respecto a la ausencia de Cecilia Rossetto en la novela la única respuesta obtenida es por qué no pensar que cantante y frases se agregaron después en España.

Las novelas argentinas de MVM reúnen décadas de proyectos literarios y pasiones del autor, nostalgias cinematográficas, anécdotas personales, amores tangueros, tributos y/o venganzas poéticas. Estas novelas son crónicas del descanto democrático sudamericano, y son también lugar de lucha y de resistencia, de memoria de los desaparecidos. Un espacio ficcional de justicia transatlántica que se convierte en un espacio meta-ficcional de injusticia: Cecilia Rossetto no es sólo la mujer oculta de la historia sino la mujer textualmente censurada, ficcionalmente desaparecida por manos anónimas, todo lo cual, como ella misma indica en el emotivo apéndice final, "resultaba como un regreso a pasados dictatoriales que conocía muy bien". La novela se vuelve así una asombrosa metáfora de la propia historia de luchas y resistencias a desaparecer de la historia. Por suerte la voz de Cecilia Rossetto no se ha apagado, ella es una mujer con una voz bellísima, desgarradora, y canta cada día mejor. Y más fuerte.

\section{Apéndice: La voz de Cecilia Rossetto: "MANOLO"}

Tuve una época en la que viví apresurada buscando ganarme la vida en medio de las marginaciones que suelen imponer los avatares políticos en Argentina y, en especial, la vereda según en la cual te instales. Eso me llevó a trabajar por distintos países de Latinoamérica y a realizar giras 
por toda España. En esos viajes solía conocer afectuosamente a decenas de personas, muchas de las cuales no volvería a ver nunca más.

Supongo que ésa es la razón que no me permite recordar con exactitud la cena donde nos encontramos por primera vez con Manuel Vázquez Montalbán. Fue en alguna casa de amigos comunes en Buenos Aires a comienzos de los 90', pero estoy convencida de que la invitación me llegó por José Comas, un gran reportero asturiano que había sido corresponsal de El País en Alemania y México y que estaba instalado en la capital porteña desde hacía varios años. Nos habíamos hecho muy amigos con Pepe y, a pesar de su fama de malhumorado, nos reíamos muchísimo. Así coincidimos en aquella cena donde, al sentirme en confianza, parece que me puse a cantar...lo poco que recuerdo es lo que el mismo Manolo relató en algún artículo.

A partir de entonces y luego de mi repentino suceso en Barcelona (incluyendo dos Premios a Mejor Actriz de los Crítica Catalana), las temporadas teatrales se sucedieron en la que se tornaría "la meva segona patria" $o$, como escribiera nuestro escritor en la contratapa del diario argentino Página 12, "Barcelona capital del rossettismo europeo". Y es ahí, más exactamente en el barrio del Raval, donde solíamos encontrarnos en rueda de camaradas, esos que festejábamos con su habitual brindis "Por la caída del régimen!". Manolo amaba comer en Casa Leopoldo a sólo tres calles de donde él nació en ese barrio de perdedores, y la generosidad de Rosa Gil, su dueña, nos reunía alrededor de las especialidades de la casa, el rabo de toro, las croquetas de jamón o el revuelto de ajos tiernos. Manolo era un enamorado de la gastronomía. Y era un experto cocinero. Pude comprobarlo en su casa de Vallvidrera en una cena que me ofreció con su esposa Anna Sallés donde me deleitó, entre muchas exquisiteces, con lo que él llamó risotto a la moscovita que consistía en un delicioso arroz cremoso coronado con caviar.

Cuando los encuentros eran en Buenos Aires caminábamos las calles empedradas y su costanera en interminables charlas, visitábamos los perfumes de las especies del El Gato Negro o tomábamos simplemente un café en mi casa. Fue justamente hasta ella que me hizo llegar la edición argentina de Quinteto de Buenos Aires que estaba por presentar en nuestra ciudad. La leí y le hice unos comentarios telefónicos, nada en especial...pero él sospechó que yo no le dijera "especialmente nada". Entonces me acercó apresurada y personalmente la edición española de tapas duras y, muy ofuscado, con la cara enrojecida revolviendo las páginas, me mostró lo que había escrito en ellas: Pepe Carvalho en Buenos Aires expresaba "Recuerdo un show de Cecilia Rossetto que ví en Espa- 
ña...Por cierto, sigo sin ver a la Rossetto...soy un detective privado, siempre buscamos a un hombre oculto, a una mujer oculta. Antes de irme quiero ver un espectáculo de Cecilia Rossetto. La ví en España y me parece genial, Después, adiós”. Hasta el último momento, al terminar la novela, Carvalho "avisa la cristalería posmoderna del aeropuerto de Barcelona. ¿Había estado en Buenos Aires? Ni siquiera había conseguido ver el show de Cecilia Rossetto."

Manolo estaba muy amargado por esa omisión que le resultaba incomprensible y, aunque a mí también me resultaba como un regreso a pasados dictatoriales que conocía muy bien, lo consolaba diciéndole " $n o$ te preocupes querido amigo, estoy acostumbrada a estas cosas en mi país, siempre me han omitido de alguna manera". Pero con esas palabras lo fastidiaba aún más, a tal punto que, en la presentación del libro en un lujoso hotel de Buenos Aires, llamó al responsable de Planeta y, en mi presencia, le exigió explicaciones. El hombre que, aparentemente, no tenía la menor idea de lo que podría haber sucedido, se deshacía en disculpas hacia él y hacia mí y me juraba y perjuraba que, en próximas ediciones, lo corregirían.

Nunca lo comprobé, ni siquiera sé si existieron otras ediciones en Argentina y jamás volví a hablar con Vazquez Montalbán del episodio...de verdad, estaba habituada a que me sucedieran cosas como esas... solamente una vez, en medio de una sesión con mi psicoanalista, le mostré las dos ediciones dedicadas por Manolo y mi terapeuta abrió los ojos asombrado y me dijo: "Ahora entiendo muchas de sus paranoias! A mí mismo me sucedería lo mismo!"

Manuel Vázquez Montalbán también las entendía. Él siempre me consideró "una fugitiva", alguien inmersa en la memoria histórica de los argentinos y en la de los españoles, conocedora de que "la historia tiene culpables" y que una "pertenece a la cultura de la resistencia", como supo escribir mi amigo del Raval.

Cecilia Rossetto, abril de 2019

\section{Bibliografía}

Castilla, Amelia. "Vázquez Montalbán cierra el 'año Carvalho' con una novela sobre la dictadura argentina". Madrid: El País, 7 de octubre 1997. Web.

Castrillo, Marina. De(...)costruzione della cittá di Buenos Aires. Tesis de Master. Universitá degli studi di Roma "La Sapienza", Julio 2011. 
Castrillo, Marina. Conversación telefónica con Editorial Planeta (Buenos Aires). 12 de marzo 2019.

Colmeiro, José. "Canciones con historia: Cultural identity, historical memory, and popular songs". Journal of Spanish Cultural Studies 4:1 (2003): 31-45. Impreso.

---. "Memories Without Borders? Spanish Court and the Case for Universal Jurisdiction". Journal of New Zealand Studies. NS 11 (2011): 109-133. Web.

Febrés, Xavier. Diccionario del tango en Catalunya. Barcelona: Casa América Catalunya, 2009. Impreso.

Garassino, Nacho. Barcelona tango, Barcelona, VHS, 2003. Producciones Doble banda. Audiovisual.

Izquierdo, José María, "Manuel Vázquez Montalbán y 'el tan esperado octavo día de la semana"”. Actas del I Congreso de Hispanistas nórdicos 2004. Acta Ibero-Americana Fennica VII. Eds. Ken Benson, José Luis Girón y Timo Riiho. Instituto Iberoamericano de Finlandia, Madrid 2007, 188-198. www.academia.edu. Web.

Lacalle Zaluendo, Charo. "Traduttore, traditore? La adaptación televisiva de «Las aventuras de Pepe Carvalho» (Adolfo Aristarain)". Signa: revista de la Asociación Española de Semiótica 25 (2016): 667-683. Web.

Musci, Mónica. "Maradona, tango, desaparecidos: la Argentina de los años noventa vista por un español". De la periferia al centro. Discurso de la otredad en la narrativa española contemporánea. Eds. Raquel Macciucci y Natalia Corbellini. La Plata: Ediciones Al Margen, 2006. 121-134. Impreso.

Otros Aires, "Rotos en El Raval", Otros Aires. 2004. Disco CD.

Pardo, Carlos, "La novela de detectives y la música: el caso del Quinteto de Buenos Aires de Manuel Vázquez Montalbán". Polifonía 3.1 (2013): 148-166.

Rico, Manuel, "La poesía de Manuel Vázquez Montalbán: un decálogo y una coda", en Manuel Vázquez Montalbán, Memoria y deseo. 9-28. Impreso.

Rossetto, Cecilia, "Manolo". Comunicación recibida por e-mail. 30 de abril 2019.

Salaün, S. "Defensa e ilustración de la canción popular según Vázquez Montalbán", en Manuel Vázquez Montalbán, el compromiso con la memoria. Ed. José F. Colmeiro. Tamesis: Woodbridge, 2007. Impreso.

Vázquez Montalbán, Manuel, Cancionero general del franquismo. 1939- 
1975. Barcelona: Crítica, 2000. Impreso.

---. Yo maté a Kennedy: impresiones, observaciones y memorias de un guardaespaldas. 1972. Barcelona: Planeta, 1987. Impreso.

---. "El placer de ser Borges", Interviú 207, 1 mayo, 1980, en Obra periodística. Volumen II: Del humor al desencanto (1974-1986), Francesc Salgado de Dios, ed. Debate: Barcelona, 2011.77-78. Impreso.

--- ."Tango o Maurice de Bellancourt pide explicaciones a la historia", Triunfo, 17 febrero 1973: 49. Web.

---. "Tango Tango Tango", Triunfo, 7 abril 1973: 20-22. Web.

---. "Corrientes 348”, El País, 16 abril, 1984. Web.

---. El pianista. 1985. Edición de José Colmeiro. Madrid: Cátedra, 2017. Impreso.

---. "Carvalho", El País, 20 marzo, 1986. Web.

--- El estrangulador, Barcelona: Mondadori, 1994. Impreso.

---. "La Rossetto", Elogis desmesurats. AVUI, 13 enero, 1996. Impreso.

---. La muchacha que pudo ser Emmanuelle. 1997. Cuentos negros. Edición de George Tyras. Barcelona. Galaxia Gutenberg. 2009. Impreso.

---. Ciudad. Madrid: Visor, 1997. Impreso.

---. Quinteto de Buenos Aires. Barcelona: Planeta, 1997. Impreso.

---. Quinteto de Buenos Aires. Buenos Aires: Planeta, 1997. Impreso.

--- "Adriana Varela, solista en el quinteto de Buenos Aires", Página/12, 10 de agosto 1998 . Web.

---. Poesía completa 1963-2003. Memoria y deseo. Barcelona: Península, 2008. Impreso.

---. "La globalización y los tanguistas", Página /12, 19 octubre 2001. Web. 